\title{
Control of Schwann cell myelination
}

\section{Kristján R Jessen* and Rhona Mirsky}

\author{
Address: Department of Cell and Developmental Biology, University College London, Gower Street, London WC1E 6BT, UK \\ * Corresponding author: Kristján R Jessen (k.jessen@ucl.ac.uk) \\ FI000 Biology Reports 2010, 2:19 (doi:10.3410/B2-19)
}

The electronic version of this article is the complete one and can be found at: http://fl000.com/reports/biology/content/2/19

\begin{abstract}
Schwann cells ensheath all axons of peripheral nerves. Only around large-diameter axons do they elaborate myelin, forming insulating sheaths that are vital for fast conduction of axon potentials. A series of recent papers has illuminated some of the ways in which the process of myelination is controlled, both by signals from axons and by positive and negative transcriptional mechanisms within the Schwann cells themselves.
\end{abstract}

\section{Introduction and context}

It has long been known that axonal signals control the induction and maintenance of the Schwann cell myelin sheath that surrounds the large-diameter axons in peripheral nerves. However, until very recently, the nature of these signals has remained obscure. In contrast, the identity of the transcription factors in Schwann cells that organise the myelination programme is much better characterised. Well-established transcriptional regulators of this programme include Krox-20 (early growth response gene 2, or Egr-2) and its associated proteins, NAB (nucleic acid-binding protein) 1 and 2, Sox-10, Oct- 6 and Brn1 and Brn2. Current knowledge of the mechanisms by which these factors exert their effects on myelination has recently been reviewed [1].

Unlike most other cell types, Schwann cells can readily dedifferentiate. Thus, when myelinating Schwann cells are deprived of axonal contact in injured nerves, they adopt a molecular and morphological phenotype that is similar, though not identical, to the phenotype of immature Schwann cells prior to myelination. Depending on circumstances, therefore, Schwann cells either provide support for mature axons by elaboration of a myelin sheath or provide an environment through which axons can regrow after injury and subsequently remyelinate. We are just beginning to form a more comprehensive picture of how Schwann cells transit between these two phenotypes, with an emerging picture of a mechanism involving cross-inhibitory interactions between positive and negative transcriptional regulators of myelination [2].

An important advance in our understanding of axonal signalling mechanisms that control myelination has occurred in the past five years. Several papers have shown that the axonal surface protein neuregulin 1 (type III 31 ), acting via its receptors ErbB2 and ErbB3, controls the thickness of the Schwann cell myelin sheath and is part of the mechanism that controls the expression of myelin genes and the induction of myelination [3-7]. This factor also controls the survival of Schwann cell precursors and is a potent mitogen for Schwann cell precursors and Schwann cells. It remains a challenge to understand the mechanism by which the Schwann cell switches its response to neuregulin from a non-myelinating proliferative phase to a non-proliferative myelination mode. Some evidence suggests that a balance between ERK (extracellular signal-related kinase) $1 / 2$ and JNK (c-Jun N-terminal kinase)/c-Jun (pro-dedifferentiation) and PI3 kinase (phosphatidyl inositol-3 kinase)/AKT (promyelination) signalling may be involved, but the picture is far from clear [8-12]. To add complications, soluble neuregulin isoforms at high concentrations can also promote demyelination [13]. Although neuregulin is required in peripheral nervous system myelination, it is not required for myelination by oligodendrocytes in the central nervous system [14]. 


\section{Major recent advances}

Recent evidence suggests that neuregulin 1 type III expressed by axons also regulates the formation of mature non-myelinating Schwann cells (Remak bundles). Genetic inactivation of neuregulin 1 type III in smallcalibre unmyelinated C-fibres, using Nav1.8-Cre mice, results in aberrant Remak fibres that contain abnormally large numbers of axons, and the altered morphology is reflected in a reduced response to noxious pressure stimulation [15]. In these mice, neuregulin 1 type III was also inactivated in small myelinated $A \delta$ fibres. This resulted in an increase in the number of axons in this size category which remained unmyelinated, despite achieving a 1:1 relationship with Schwann cells. This is in line with earlier evidence that neuregulin 1 type III promotes myelination, as discussed above. Despite the altered morphology, the nerves of these mutant mice contain normal numbers of axons and Schwann cells.

One of the ways in which neuregulin signalling is likely to control myelination is by increasing the $\mathrm{Ca}^{2+}$ level in Schwann cells. This activates the phosphatase calcineurin, which dephosphorylates nuclear factor of activated $\mathrm{T}$ cells (NFAT) c3 and c4, resulting in translocation to the nucleus. Kao and colleagues [16] show that deleting calcineurin B specifically in the Schwann cell lineage results in defects in radial sorting and hypomyelination in newborn mice. Because the mice die shortly after birth, it is not possible to say whether the hypomyelination is transient or permanent. Lack of calcineurin B prevents neuregulin-induced dephosphorylation and activation of NFAT c3 and c4. Furthermore, NFAT c 4 complexes with Sox-10, a transcription factor required for myelination [17], to activate the promoter and myelin-specific enhancer of the Krox-20 gene, which globally regulates peripheral myelination $[11,18-20]$, and also with the promoter of the myelin protein zero $\left(P_{0}\right)$ gene, all of which underline the involvement of NFAT proteins in myelination.

It has long been known that elevation of intracellular cyclic AMP levels induces cultured Schwann cells to express myelin proteins and adopt many other aspects of the myelinating Schwann cell phenotype, suggesting that cAMP is part of the signalling system that promotes myelination [21]. A recent paper now provides important in vivo evidence for this proposition [22]. In experiments using mutant zebrafish, the authors found that the G protein-coupled receptor GPR126 is essential for myelination in the peripheral nervous system and that the defect is confined to signalling within Schwann cells rather than axons. Significantly, treatment of the developing mutant fish with forskolin, which elevates intracellular cAMP levels, restores myelination, suggesting that this orphan receptor acts by controlling Schwann cell cAMP levels. Because levels of neuregulin and ErbB3 receptors remain normal in the mutant fish, it is likely that GPR126 functions independently of neuregulin to regulate myelination. Additional evidence for the involvement of cAMP and cAMP-dependent protein kinase A (PKA) in myelination comes from studies of the transcription factor nuclear factor-kappa-B (NF-kB) [23]. In Schwann cell-dorsal root ganglion (DRG) co-cultures, inhibition of NF-kB activation inhibits proper association of Schwann cells with axons and myelination, and co-cultures using cells from mice lacking the $\mathrm{p} 65$ active subunit of NF- $\mathrm{kB}$ show marked inhibition of myelination [24]. Significantly, phosphorylation of the p65 subunit by PKA increases transcriptional activity but not DNA binding and is required for upregulation of Oct- 6 by cAMP. Although the experiments remain to be confirmed in vivo, the results suggest that this factor transduces cAMP signals within Schwann cells and promotes myelination at early stages of myelin induction. Linking these findings to those from zebrafish, it may also be significant that there are two binding sites for NF-kB within the GPR126 promoter.

Cell-cell interactions between axons and Schwann cells are vital to the process of myelination. Two recent papers reveal new roles for nectin-like cell adhesion molecules (Necls), members of the immunoglobulin superfamily of cell adhesion molecules, at the onset of myelination $[25,26]$. Necl2 and Necl4 are expressed in Schwann cell membranes, principally in the internodal region and in Schmidt-Lanterman incisures while Necl1 and Necl2 are expressed by axons. Necl4 interacts heterophilically with Necl1, expressed on axons, to facilitate myelination. Knockdown of Necl4 by shRNA (short hairpin RNA) severely inhibits myelination in DRG-Schwann cell cocultures. Although Schwann cells can line up along the axons and even enclose them, they fail to make even 1.5 turns around the axons, pointing to a requirement for these proteins at the early stages of myelination to ensure proper wrapping and spiralling of the Schwann cell membrane. In addition, levels of the transcription factors Oct- 6 and Krox-20 remain low in these co-cultures. It remains to be determined, however, whether this phenotype will be reproduced by knockout of $\mathrm{Necl} 4$ in vivo.

In addition to transcription factors that promote myelination, such as NFAT, NF- $\kappa$ B, Sox-10, Krox-20 and Oct-6 (discussed above), there is increasing evidence that myelin differentiation is subject to negative transcriptional regulation. In vivo, selective inactivation of Notch 1 in Schwann cells accelerates myelination while overexpression of the active intracellular domain of Notch (NICD) delays it, indicating that myelination is negatively controlled by Notch signalling [27]. The major role of negative regulation is likely to be that of driving Schwann cell demyelination/dedifferentiation. NICD levels rise 
rapidly in injured nerves, and the resulting demyelination is slower if the NICD elevation is prevented. Conversely, demyelination is accelerated in injured nerves engineered to overexpress NICD. Even in uninjured nerves, activation of Notch is sufficient to induce rapid demyelination [27]. Another transcription regulator, c-Jun, is similarly elevated in the Schwann cells of injured nerves, and as with Notch 1, demyelination is delayed when this elevation is prevented [12]. c-Jun is also required for the generation of the characteristic molecular and morphological phenotype of the dedifferentiated cell [28]. Other transcription factors that negatively regulate myelin differentiation in cell culture include Sox2 and Id2 and Id4 [2,29].

\section{Future directions}

Lipids form major components of the myelin sheath and we are just beginning to explore how myelin lipid synthesis is synchronised with that of the myelin proteins [30-32]. The pathways activated by established Schwann cell signals, such as CAMP and neuregulin, are actively being clarified as exemplified by the work on GPR126 and NF- $\kappa$ B mentioned above and by the recent identification of BACE1 ( $\beta$-site APP cleaving enzyme), the PDZ (post-synaptic density 95-discs large-zonula occludens 1) domain protein erbin and the tyrosine phosphatase Shp2 (src homology 2 domaincontaining protein tyrosine phosphatase 2) as participants in neuregulin signalling and myelination [33-36]. The downstream targets of novel Schwann cell signalling molecules (for example, the Necl proteins) will also have to be determined. We can expect to learn more about the role of epigenetic mechanisms in myelination and to understand more about how positive and negative transcriptional regulators of myelination are integrated at the molecular level and how they exert control over the promoter regions, intronic elements and downstream elements of myelin genes [1].

The mechanisms that control radial sorting and the generation of the pro-myelin cell, a prerequisite for myelination, are the focus of extremely active investigation outside the scope of this commentary. Rapid progress can be expected in this field in the near future.

Surprisingly, recent work shows that normal prion protein is involved in the control of myelin maintenance. Ablation of this prion protein in mice results in a chronic demyelinating neuropathy, although myelin is initially formed normally. The authors show that depletion of prion protein in neurons but not Schwann cells triggers the neuropathy, and that cleavage of the protein at the amino terminal end is required. It remains to be determined whether axonal prion protein interacts directly with Schwann cells or whether this protein affects myelin maintenance indirectly [37].

\section{Abbreviations}

DRG, dorsal root ganglion; GPR126, G protein-coupled receptor 126; Necl, nectin-like cell adhesion molecule; NF- $\kappa B$, nuclear factor-kappa-B; NFAT, nuclear factor of activated T cells; NICD, Notch intracellular domain; PKA, protein kinase A.

\section{Competing interests}

The authors declare that they have no competing interests.

\section{Acknowledgements}

The authors are supported by a programme grant from the Wellcome Trust, and a project grant from the Medical Research Council of Great Britain. The research leading to results from our laboratory has also received funding from the European Community's Seventh Framework Programme (FP7/2007-2013) under grant agreement HEALTH-F2-2008-201535.

\section{References}

I. Svaren J, Meijer D: The molecular machinery of myelin gene transcription in Schwann cells. Glia 2008, 56:I54I-5I.

2. Jessen KR, Mirsky R: Negative regulation of myelination: relevance for development, injury and demyelinating disease. Glia 2008, 56: I552-65.

3. Garratt AN, Voiculescu O, Topilko P, Charnay P, Birchmeier C: $A$ dual role of erbB2 in myelination and in expansion of the schwann cell precursor pool. J Cell Biol 2000, I48:I035-46.

4. Michailov GV, Sereda MW, Brinkmann BG, Fischer TM, Haug B, Birchmeier C, Role L, Lai C, Schwab MH, Nave KA: Axonal neuregulin-I regulates myelin sheath thickness. Science 2004, 304:700-3

FI000 Factor 3.2 Recommended

Evaluated by Elior Peles 06 Apr 2004, Manzoor Bhat 19 May 2004

5. Taveggia C, Zanazzi G, Petrylak A, Yano H, Rosenbluth J, Einheber S, Xu X, Esper RM, Loeb JA, Shrager P, Chao MV, Falls DL, Role L, Salzer JL: Neuregulin-I type III determines the ensheathment fate of axons. Neuron 2005, 47:681-94.

FI000 Factor 4.8 Must Read

Evaluated by Brian Popko I4 Sep 2005, Klaus-Armin Nave 19 Sep 2005

6. Chen S, Velardez MO, Warot X, Yu ZX, Miller SJ, Cros D, Corfas G: Neuregulin I-erbbB signalling is necessary for normal myelination and sensory function. J Neurosci 2006, 26:3079-86.

7. Lyons DA, Pogoda HM, Voas MG, Woods IG, Daimond B, Nix R, Arana N, Jacobs J, Talbot WS: erbB3 and erbB2 are essential for Schwann cell migration and myelination in zebrafish. Curr Biol 2005, I 5:513-24.

8. Harrisingh MC, Perez-Nadales E, Parkinson DB, Malcolm DS, Mudge AW, Lloyd AC: The Ras/Raf/ERK signaling pathway drives Schwann cell dedifferentiation. EMBO J 2004, 23:306 I-7I.

9. Maurel P, Salzer JL: Axonal regulation of Schwann cell proliferation and survival and the initial events of myelination requires PI 3-kinase activity. J Neurosci 2000, 20:4635-45.

10. Ogata T, lijima S, Hoshikawa S, Miura T, Yamamoto S, Oda H, Nakamura K, Tanaka S: Opposing extracellular signal-regulated kinase and Akt pathways control Schwann cell myelination. J Neurosci 2004, 24:6724-32.

II. Parkinson DB, Bhaskaran A, Droggiti A, Dickinson S, D'Antonio M, Mirsky R, Jessen KR: Krox-20 inhibits Jun-NH2-terminal kinasel 
c-Jun to control Schwann cell proliferation and death. / Cell Biol 2004, 164:385-94.

12. Parkinson DB, Bhaskaran A, Arthur-Farraj P, Nonn LA, Woodhoo A, Lloyd AC, Feltri ML, Wrabetz L, Behrens A, Mirsky R, Jessen KR: c-Jun is a negative regulator of myelination. J Cell Biol 2008, | 81:625-37.

FI000 Factor 3.0 Recommended

Evaluated by Chaya Kalcheim 04 Jun 2008

13. Guertin AD, Zhang DP, Mak KS, Alberta JA, Kim HA: Microanatomy of axon/glial signaling during Wallerian degeneration. J Neurosci 2005, 25:3478-87.

14. Brinkmann BG, Agarwal A, Sereda MW, Garratt AN, Müller T, Wende H, Stassart RM, Nawaz S, Humml C, Velanac V, Radyushkin K, Goebbels S, Fischer TM, Franklin RJ, Lai C, Ehrenreich H, Birchmeier C, Schwab MH, Nave KA: Neuregulin- I/ErbB signaling serves distinct functions in myelination of the peripheral and central nervous system. Neuron 2008, 59:58I-95.

FI000 Factor 9.0 Exceptional

Evaluated by Rhona Mirsky 29 Sep 2008

15. Fricker FR, Zhu N, Tsantoulas C, Abrahamsen B, Nassar MA, Thakur M, Garratt AN, Birchmeier C, McMahon SB, Wood JN, Bennett DL: Sensory axon-derived neuregulin- $I$ is required for axoglial signaling and normal sensory function but not for long-term axon maintenance. J Neurosci 2009, 29:7667-78.

FI000 Factor 6.0 Must Read

Evaluated by Rhona Mirsky 14 Jul 2009

16. Kao SC, Wu H, Xie J, Chang CP, Ranish JA, Graef IA, Crabtree GR: Calcineurin/NFAT signaling is required for neuregulin-regulated Schwann cell differentiation. Science 2009, 323:65I-4.

FI000 Factor 6.4 Must Read

Evaluated by Raymond Harris 22 Apr 2009, Klaus-Armin Nave 06 Mar 2009

17. Schreiner S, Cossais F, Fischer K, Scholz S, Bösl MR, Holtmann B, Sendtner M, Wegner M: Hypomorphic Sox 10 alleles reveal novel protein functions and unravel developmental differences in glial lineages. Development 2007, |34:327|-8I.

18. Topilko P, Schneider-Manoury S, Levi G, Baron-Van Evercooren A, Chennoufi ABY, Seitanidou T, Babinet C, Charnay P: Krox-20 controls myelination in the peripheral nervous system. Nature 1994, 371:796-9.

19. Nagarajan R, Svaren J, Le N, Araki T, Watson M, Milbrandt J: EGR2 mutations in inherited neuropathies dominant-negatively inhibit myelin gene expression. Neuron 200I, 30:355-68.

20. Ghislain J, Charnay P: Control of myelination in Schwann cells: a Krox20 cis-regulatory element integrates Oct6, Brn2 and Sox 10 activities. EMBO Rep 2006, 7:52-8.

21. Mirsky $R$, Jessen KR: Molecular signalling in Schwann cell development. In Peripheral Neuropathy. Vol. I. 4th edition. Edited by Dyck PJ, Thomas PK. Philadelphia: Elsevier Saunders; 2005:34I-376.

22. Monk KR, Naylor SG, Glenn TD, Mercurio S, Perlin JR, Dominguez C, Moens CB, Talbot WS: A G protein-coupled receptor is essential for Schwann cells to initiate myelination. Science 2009, 325:402-5.

FI000 Factor 6.0 Must Read

Evaluated by Klaus-Armin Nave 16 Sep 2009

23. Yoon C, Korade Z, Carter BD: Protein kinase A-induced phosphorylation of the $\mathbf{6 5} 5$ subunit of nuclear factor-kappaB promotes Schwann cell differentiation into a myelinating phenotype. J Neurosci 2008, 28:3738-46.

24. Nickols JC, Valentine W, Kanwal S, Carter BD: Activation of the transcription factor NF-kappaB in Schwann cells is required for peripheral myelin formation. Nat Neurosci 2003, 6:16I-7.

FI000 Factor 3.0 Recommended

Evaluated by Elior Peles 04 Feb 2003
25. Maurel P, Einheber S, Galinska J, Thaker P, Lam I, Rubin MB, Scherer SS, Murakami Y, Gutmann DH, Salzer JL: Nectin-like proteins mediate axon Schwann cell interactions along the internode and are essential for myelination. J Cell Biol 2007, I 78:86I-74.

FI000 Factor 3.3 Recommended

Evaluated by Vance Lemmon 12 Sep 2007, Rhona Mirsky 18 Sep 2007, Yoshimi Takai II Oct 2007

26. Spiegel I, Adamsky K, Eshed Y, Milo R, Sabanay H, Sarig-Nadir O, Horresh I, Scherer SS, Rasband MN, Peles E: A central role for Necl4 (SynCAM4) in Schwann cell-axon interaction and myelination. Nat Neurosci 2007, 10:86I-9.

FI000 Factor 6.5 Must Read

Evaluated by Brian Popko 19 Jun 2007, Klaus-Armin Nave 25 Jun 2007, Rhona Mirsky 19 Sep 2007

27. Woodhoo A, Alonso MB, Droggiti A, Turmaine M, D'Antonio M, Parkinson DB, Wilton DK, Al-Shawi R, Simons P, Shen J, Guillemot F, Radtke F, Meijer D, Feltri ML, Wrabetz L, Mirsky R, Jessen KR: Notch controls embryonic Schwann cell differentiation, postnatal myelination and adult plasticity. Nat Neurosci 2009, I 2:839-47.

FI000 Factor 6.0 Must Read Evaluated by Brian Popko I8 Jun 2009

28. Wilton $D$, Arthur-Farraj $P$, Latouche M, Turmaine M, Behrens A Mirsky R, Raivich G, Jessen KR: Schwann cell c-Jun is essential for peripheral nerve regeneration. Glia 2009, 57:SI58. Poster 542.

29. Le N, Nagarajan R, Wang JY, Araki T, Schmidt RE, Milbrandt J: Analysis of congenital hypomyelinating Egr2Lo/Lo nerves identifies Sox2 as an inhibitor of Schwann cell differentiation and myelination. Proc Natl Acad Sci U S A 2005, 102:2596-60I.

30. Leblanc SE, Srinivasan R, Ferri C, Mager GM, Gillian-Daniel AL, Wrabetz L, Svaren J: Regulation of cholesterol/lipid biosynthetic genes by Egr2/Krox20 during peripheral nerve myelination. j Neurochem 2005, 93:737-48.

31. Saher G, Quintes S, Möbius W, Wehr MC, Krämer-Albers EM, Brügger $B$, Nave KA: Cholesterol regulates the endoplasmic reticulum exit of the major membrane protein $\mathrm{PO}$ required for peripheral myelin compaction. J Neurosci 2009, 29:6094-I04.

32. Verheijen MH, Camargo N, Verdier V, Nadra K, de Preux Charles AS, Médard JJ, Luoma A, Crowther M, Inouye H, Shimano H, Chen S, Brouwers JF, Helms JB, Feltri ML, Wrabetz L, Kirschner D, Chrast R, Smit $A B$ : SCAP is required for timely and proper myelin membrane synthesis. Proc Natl Acad Sci U S A 2009, 106:21383-8.

33. Hu X, Hicks CW, He W, Wong P, Macklin WB, Trapp BD, Yan R: Bacel modulates myelination in the central and peripheral nervous system. Nat Neurosci 2006, 9:1520-5.

34. Willem M, Garratt AN, Novak B, Citron M, Kaufmann S, Rittger A, DeStrooper B, Saftig P, Birchmeier C, Haass C: Control of peripheral nerve myelination by the beta-secretase BACEI. Science 2006, 3|4:664-6.

FI000 Factor 3.2 Recommended Evaluated by Klaus-Armin Nave 16 Oct 2006, Brian Popko 0 I Nov 2006

35. Tao Y, Dai P, Liu Y, Marchetto S, Xiong W-C, Borg J-P, Mei L: Erbin regulates NRG I signaling and myelination. Proc Natl Acad Sci U S A 2009, 106:9477-82.

FI000 Factor 3.0 Recommended Evaluated by Kristjan R Jessen 10 Jun 2009

36. Grossmann KS, Wende H, Paul FE, Cheret C, Garratt AN, Zurborg S, Feinberg K, Besser D, Schulz H, Peles E, Selbach M, Birchmeier W, Birchmeier C: The tyrosine phosphatase Shp2 (PTPNII) directs Neuregulin-I/ErbB signaling throughout Schwann cell development. Proc Natl Acad Sci U S A 2009, 106:16704-9.

37. Bremer J, Baumann F, Tiberi C, Wessig C, Fischer H, Schwarz P, Steele AD, Toyka KV, Nave KA, Weis J, Aguzzi A: Axonal prion protein is required for peripheral myelin maintenance. Nat Neurosci 2010, 13:310-8. 